As-Syifaa Vol 09 (02) : Hal. 165-172, Desember 2017

ISSN : 2085-4714

\title{
AKTIVITAS ANTIBAKTERI EKSTRAK ETANOL BATANG Phytocrene macrophylla BLUME.
}

\author{
Herwin, Firna Anggriani Mile \\ Fakultas Farmasi Universitas Muslim Indonesia, Makassar \\ Email : herwinfarmasi@gmail.com
}

\begin{abstract}
Antibacterial activity test has been done on Phytocrene macrophylla Blume stem ethanol extracts. The aim of the research was to determine the antibacterial activity of Phytocrene macrophylla Blume Stem Ethanol extracts delivered from Gowa District of South Sulawesi by means of Agar Diffusion. The results of the screening antibacterial activity of ethanol extracts of stem Phytocrene macrophylla Blume possessed activity against Escherichia coli, Streptococcus mutans, and Pseudomonas aeroginosa. At the minimum inhibitory concentration tests used the concentrations of $0,2 \%, 0,4 \%, 0,6 \%, 0,8 \%, 1 \%, 5 \%, 10 \%$, and $15 \%$ of the bacteria Streptococcus mutans, Pseudomonas aeroginosa, and Escherichia coli can inhibit $0,2 \%$. At the minimum kill concentration test against the bacteria Streptococcus mutans and Pseudomonas aeroginosa inhibited at the concentration of $0,8 \%$ and the bacteria Escherichia coli at the concentration of $1 \%$. The test results of antibacterial activity of ethanol extract of stem Phytocrene macrophylla Blume at the concentrations of $0.8 \%, 1 \%$, and $5 \%$ inhibited the growth of bacteria. The biggest inhibitory zone of the test conducted, that is, at the concentration of $5 \%$ by $16 \mathrm{~mm}$ against to the bacteria Pseudomonas aeroginosa and Streptococcus mutans, and 14 $\mathrm{mm}$ to Escherichia coli.
\end{abstract}

Key words : Ethanol Extract of Stem Phytocrene macrophylla Blume, Agar Diffusion, Antibacterial.

PENDAHULUAN

Pemanfaatan dan kebutuhan tanaman sebagai obat sekarang ini merupakan peluang besar untuk pengembangan obat tradisional yang efek samping sangat relatif kecil dibandingkan dengan obat modern namun diperlukan pengujian aktivitas dan pengujian pra-klinis untuk mengetahui khasiat, dosis dan keamanan sebagai obat tradisional tersebut. Salah satu tanaman yang belum termanfatkan oleh masyarakat adalam tumbuhan Phytocrene macrophylla Blume. sehingga diperlukan adanya pemanfaatan 
Aktivitas antibakteri ekstrak etanol batang Phytocrene macrophylla Blume.

secara ilmiah sehingga penggunaan dalam masyarakat terutama dalam pengobatan infeksi dapat terealisasikan.

Penyakit infeksi merupakan salah satu masalah dalam dunia kesehatan, dan hampir semua negara mengalami penyakit infeksi. ${ }^{1}$ Sehingga para ilmuwan berusaha mencari sumber antibakteri yang baru yang berasal baik dari tumbuh-tumbuhan maupun dari hewan, terutama yang berada di Indonesia yang daoat dijadikan sebagai obat tradisional sebagai alternatif opencarian zat antibakteri, karena adanya kandungan kimia aktif yang sangat berperan penting dalam bidang kesehatan terutama dalam pengobatan infeksi.

Penelusuran obat-obat baru dari tumbuhan dilakukan berdasarkan penelusuran tumbuhan yang tidak teridentifikasi maupun yang teridentifikasi manfaat dan kandungannya. Tumbuhan yang masih sangat kurang teridentifikasi kandungan dan manfaatnya adalah tumbuhan Phytocrene macrophylla Blume. Penelitian sebelumnya menjelaskan bahwa ekstrak etanol batang tumbuhan Phytocrene macrophylla Blume. terhadap bakteri uji secara KLT-Bioautografi bahwa ekstrak etanol batang tumbuhan
Phytocrene macrophylla Blume. menunjukkan bercak pada kromatogram menggunakan eluen $\mathrm{n}$ Heksan : Etil Asetat (5:1) nilai Rf. 0.95 aktif terhadap bakteri Staphylococcus aureus dan nilai Rf. 0.81 aktif terhadap bakteri Eschericia coli. Dan hasil identifikasi golongan komponen kimia aktif menunjukkan bahwa nilai Rf. 0.95 merupakan golongan flavanoid dengan menggunakan pereaksi kimia aluminium klorida. $^{2}$

Berdasarkan hal tersebut maka akan dilakukan penelitian aktivitas antibakteri ekstrak etanol batang tumbuhan Phytocrene macrophylla Blume. sehingga penggunaannya dalam masyarakat lebih dapat termanfaatkan dan dipertanggungjawabkan.

\section{METODE PENELITIAN}

\section{Alat dan Bahan Penelitian}

Alat yang digunakan pada penelitian ini adalah autoklaf, (Smic Model YX-280 B), botol pengencer, cawan petri, gelas erlenmeyer $250 \mathrm{ml}$ (Iwaki Pyrex), enkas, gelas ukur 100 ml (Iwaki Pyrex), gelas kimia $250 \mathrm{ml}$ (Iwaki Pyrex), inkubator (Memmert), Laminar Air Flow (LAF), lampu spiritus, oven (Fisher), Lempeng kromatografi lapis tipis (TLC Silika Gel G $60 \quad F_{254}$ ), Spektrofotometri UV-visibel, timbangan analitik danTimbangan 
kasar. Bahan yang digunakan pada penelitian ini adalah air suling, etanol $96 \%$, larutan $\mathrm{NaCl}$ 0,9\%, medium Nutrien agar (NA), medium Nutrien Broth (NB), Kultur bakteri pathogen (Basillus subtilis, Escherichia coli, Staphylococcus aureus, Salmonella typhi, Pseudomonas aeruginosa, Vibrio cholerae, Streptococcus mutans, Staphylococcus epidermidis dan Shigella dysentriae), dan Batang tumbuhan Phytocrene macrophylla Blume.

\section{Prosedur Penelitian}

Determinasi Tumbuhan Phytocrene macrophylla Blume. ${ }^{5}$

Tumbuhan

Phytocrene macrophylla Blume. dari kabupaten Gowa provinsi Sulawesi Selatan dilakukan determinasi tumbuhan di laboratorium Farmakognoni-Fitokimia Fakultas Farmasi Universitas Muslim Indonesia untuk mengetahui species tumbuhan yang digunakan sebagai sampel penelitian.

\section{Ekstraksi Batang Tumbuhan Phytocrene macrophylla Blume. Secara Maserasi}

Batang tumbuhan
macrophyllacrene
sebanyak 500 gram kemudian
dimasukkan ke dalam wadah
maserasi, lalu ditambahkan etanol
$96 \%$ (hingga simplisia tersebut

terendam) dan dibiarkan selama 5 hari dengan pengadukan sesering mungkin dalam bejana tertutup dan terlindung dari cahaya. Setelah itu disaring dan ampasnya direndam lagi dengan cairan penyari yang baru. Hal ini dilakukan hingga proses ekstraksi sempurna. Hasil penyarian yang didapat kemudian diuapkan dengan menggunakan rotavapor hingga diperoleh ekstrak etanol kental.

\section{Uji Skrining Aktivitas Anbibakteri} Ekstrak Etanol Batang Tumbuhan Phytocrene macrophylla Blume.

Ekstrak etanol batang tumbuhan Phytocrene macrophylla Blume. Ditimbamg sebanyak $10 \mathrm{mg}$ lalu dilarutkan dengan Dimetil Sulfoxida (DMSO) sebanyak $0.2 \mathrm{~mL}$. Setelah larut, ekstrak ditambahkan dengan medium Nutrien Agar sebanyak $9.8 \mathrm{~mL}$ kemudian dituang kedalam cawan petri lalu dihomogenkan dan dibiarkan memadat. Mikroba yang telah disuspensikan, masing-masing diambil menggunakan ose bulat lalu digoreskan pada medium yang telah memadat kemudian diinkubasi pada suhu $37^{\circ} \mathrm{C}$ selama $1 \times 24$ jam. Hasil inkubasi diamati aktivitas antibakteri yang ditandai dengan ada tidaknya pertumbuhan bakteri pada medium. 
Pengujian Kosentrasi Hambat Minimum (KHM) Ekstrak Etanol Tumbuhan Phytocrene macrophylla Blume $^{3,4}$

Ekstrak etanol batang tumbuhan Phytocrene macrophylla Blume. dibuat variasi kosentrasi $0.2 \%$, $0.4 \%, 0.6 \%, 0.8 \%, 1 \%, 5 \%, 10 \%$ dan $15 \%$, kemudian dimasukkan kedalam masing-masing tabung reaksi steril, lalu ditambahkan $5 \mathrm{~mL}$ medium Nutrien Broth dan dimasukkan suspensi bakteri uji dan dihomogenkan. Hasil homogenisasi kemudian diinkubasi pada suhu $37^{\circ} \mathrm{C}$ selam 1×24 jam. Hasil kosentrasi terendah yang menunjukkan larutan jernih adalah merupakan nilai KHMnya.

\section{Pengujian Kosentrasi Bunuh Minimum (KHM) Ekstrak Etanol} Tumbuhan Phytocrene macrophylla Blume $^{3,4}$

Hasil inkubasi pada KHM kemudian masing-masing digores pada medium Nutrien Agar dalam cawan petri steril, kemudian diinkubasi pada suhu $37^{\circ} \mathrm{C}$ selama $1 \times 24$ jam. Nilai Kosentrasi Bunuh Minimum (KBM) ditunjukkan pada nilai terendah yang tidak menunjukkan adanya pertumbuhan bakteri uji.

$\begin{array}{lll}\text { Pengujian } & \text { Aktivitas } & \text { Antibakteri } \\ \text { Ekstrak } & \text { Etanol } & \text { Tumbuhan }\end{array}$

Phytocrene macrophylla Blume. Secara Difusi Agar

Medium Nutrien Agar (NA) yang telah dipanaskan dan disterilkan kemudian didinginkan hingga $40-50^{\circ} \mathrm{C}$ lalu dimasukkan secara aseptis kedalam cawan petri steril sebanyak $10 \mathrm{~mL}$ dan ditambahkan $0.02 \mathrm{~mL}$ suspensi bakteri uji lalu dibiarkan memadat. Variasi kosentrasi ekstrak etanol etanol batang tumbuhan Phytocrene macrophylla Blume. yaitu $0.8 \%, 1 \%$ dan $5 \%$ dimasukkan disk blank kedalam variasi kosentrasi sampel uji. Disk blank yang telah terendam kemudian ditempelkan didalam cawan petri yang telah berisi medium dan bakteri uji dan dinkubasi pada suhu $37^{\circ} \mathrm{C}$ selam $1 \times 24$ jam, lalu dilalukan pengamatan dan diukur diameter zona hambat yang terbentuk disekitar disk blank.

\section{Pengumpulan Data Dan Analisis} Data

Data yang diperoleh dari hasil penelitian dilakukan pengumpulan data berdasarkan determinasi sampel, ekstraksi, uji skrining aktivitas antibakteri, uji KHM, uji KBM dan uji aktivitas antibakteri secara difusi agar kemudian dianalisis berdasarkan diameter zona hambat yang terbentuk dari variasi kosentrasi yang dapat menghambat pertumbuhan bakteri uji. 


\section{HASIL PENELITIAN}

Tabel 1. Hasil Pengujian Skrinig Aktivitas Antibakteri Ekstrak Etanol Batang Phytocrene macrophylla Blume. Terhadap Bakteri Uji.

\begin{tabular}{|c|c|c|c|c|c|c|c|c|}
\hline \multirow{2}{*}{ No. } & \multirow{2}{*}{ Sampel } & \multicolumn{7}{|c|}{ Bakteri Uji } \\
\hline & & SD & SM & BS & SE & PA & SA & EC \\
\hline 1. & $\begin{array}{l}\text { Ekstrak Etanol Batang Tumbuhan } \\
\text { Phytocrene macrophylla Blume. }\end{array}$ & - & + & - & - & + & - & + \\
\hline $\begin{array}{l}\text { Keter } \\
\text { SD : } \\
\text { SM }: \\
\text { BS : } \\
\text { SE : }\end{array}$ & $\begin{array}{l}\text { angan : } \\
\text { : Shigella disentriae } \\
\text { Strekatococcus mutans } \\
\text { Bacillus subtilis } \\
\text { Staphylococcus epidermidis }\end{array}$ & $\begin{array}{l}P \\
S \\
E \\
-: \\
+\end{array}$ & $\begin{array}{l}: \text { Pse } \\
: \text { Sta } \\
: \text { Esc } \\
\text { idak m } \\
: \text { Men }\end{array}$ & $\begin{array}{l}\text { domol } \\
\text { yyloco } \\
\text { ericia } \\
\text { ngham } \\
\text { hamba }\end{array}$ & $\begin{array}{l}\text { as aer } \\
\text { cus at } \\
\text { oli } \\
\text { pat pe } \\
\text { pertu }\end{array}$ & $\begin{array}{l}\text { ginos } \\
\text { eus }\end{array}$ & $\begin{array}{l}\text { an bal } \\
\text { bakte }\end{array}$ & $\begin{array}{l}\text { eri uj } \\
\text { uji }\end{array}$ \\
\hline
\end{tabular}

Tabel 2. Hasil Pengujian Kosentrasi Hambat Minimum (KHM) Ekstrak Etanol Batang Tumbuhan Phytocrene macrophylla Blume.

\begin{tabular}{cccccccccc}
\hline & \multicolumn{7}{c}{ Kosentrasi Ekstrak } \\
\cline { 2 - 8 } Bakteri Uji & $\mathbf{0 . 2 \%}$ & $\mathbf{0 . 4 \%}$ & $\mathbf{0 . 6 \%}$ & $\mathbf{0 . 8 \%}$ & $\mathbf{1} \%$ & $\mathbf{5} \%$ & $\mathbf{1 0 \%}$ & $\mathbf{1 5 \%}$ \\
\hline SM & - & + & + & + & + & + & + & + \\
PA & - & + & + & + & + & + & + & + \\
EC & - & + & + & + & + & + & + & + \\
\hline
\end{tabular}

\section{Keterangan :}

SM : Streptococcus mutans

PA : Presudomonas aeruginosa

EC : Eschericia coli

- $\quad$ : Tidak menghambat pertumbuhan bakteri uji

$+\quad$ : Menghambat pertumbuhan bakteri uji

Tabel 3. Hasil Pengujian Kosentrasi Bunuh Minimum (KBM) Ekstrak Etanol Batang Tumbuhan Phytocrene macrophylla Blume.

\begin{tabular}{ccccccccc}
\hline & \multicolumn{7}{c}{ Kosentrasi Ekstrak } \\
\cline { 2 - 9 } Bakteri Uji & $0.2 \%$ & $0.4 \%$ & $0.6 \%$ & $0.8 \%$ & $1 \%$ & $5 \%$ & $10 \%$ & $15 \%$ \\
\hline SM & - & - & - & + & + & + & + & + \\
PA & - & - & - & + & + & + & + & + \\
EC & - & - & - & - & + & + & + & + \\
\hline
\end{tabular}

\section{Keterangan :}

SM : Streptococcus mutans

PA : Presudomonas aeruginosa

EC : Eschericia coli

- : Tidak menghambat pertumbuhan bakteri uji

$+\quad$ : Menghambat pertumbuhan bakteri uji 
Tabel 4. Hasil Pengujian Aktivitas Antibakteri Ekstrak Etanol Batang Tumbuhan Phytocrene macrophylla Blume. Secara Difusi Agar

\begin{tabular}{ccccccc}
\hline \multirow{2}{*}{ Bakteri } & \multicolumn{6}{c}{ Diameter Zona Hambatan (mm) } \\
\cline { 2 - 7 } & $\mathbf{R 1}$ & $\mathbf{0 . 8} \mathbf{R}$ & $\mathbf{R 1}$ & $\mathbf{R 2}$ & $\mathbf{R 1}$ & $\mathbf{R 2}$ \\
\cline { 2 - 7 } & 9 & 10 & 12 & 12 & 18 & 16 \\
PA & 9 & 10 & 12 & 12 & 14 & 16 \\
& 9 & 10 & 12 & 12 & 18 & 16 \\
\hline Jumlah & 27 & 30 & 36 & 36 & 50 & 48 \\
\hline Rata-Rata & 9 & 10 & 12 & 12 & 16.7 & 16 \\
\hline & 10 & 10 & 12 & 12 & 18 & 16 \\
SM & 10 & 10 & 12 & 12 & 18 & 16 \\
& 10 & 10 & 12 & 12 & 18 & 16 \\
\hline Jumlah & 30 & 30 & 36 & 36 & 54 & 48 \\
\hline Rata-Rata & 10 & 10 & 12 & 12 & 18 & 16 \\
\hline & 9 & 10 & 12 & 12 & 18 & 14 \\
EC & 9 & 10 & 12 & 12 & 17 & 14 \\
& 9 & 10 & 12 & 12 & 18 & 14 \\
\hline Jumlah & 27 & 30 & 12 & 12 & 53 & 42 \\
\hline Rata-Rata & 9 & 10 & 36 & 36 & 17.7 & 14 \\
\hline
\end{tabular}

Keterangan :

SM : Streptococcus mutans

PA : Presudomonas aeruginosa

EC : Eschericia coli

R1 : Replikasi 1

R2 : Replikasi 2

\section{PEMBAHASAN}

Berdasarkan hasil determinasi Tumbuhan Phytocrene macrophylla Blume. merupakan tumbuhan yang berasal dari kabupaten Gowa provinsi Sulawesi Selatan yang umumnya tumbuh didalam hutan dengan cara menjalar dpermukaan tanah dan pepohonan. Tumbuhan ini memiliki ciri dengan batang pokok yang jelas berkulit coklat, bangun daunnya bulat dengan ujung daun yang merucing (Acuminatus), pertulangan daun menyirip, serta beunga yang berwearna kekuningan secara berantai. Berdasarkan hasil determinasi dari Divisi Botani Laboratorium Farmakognoni-Fitokimia Fakultas Farmasi Universitas Muslim Indonesia diperoleh bahwa sampel yang digunakan dengan genus Phytocrene dan species Phytocrene macrophylla Blume.

Tumbuhan

Phytocrene macrophylla Blume. dibuat dalam bentuk simplisia dengan cara batang yang dolah dengan cara dipotongpotong kecil dan dikeringkan hingga 
Aktivitas antibakteri ekstrak etanol batang Phytocrene macrophylla Blume.

diperoleh kadar air 8.5\% kemudian diekstrasi dengan metode maserasi yaitu sebanyak 500 gram menggunakan etanol 96\% hingga diperoleh 23.5 gram ekstrak etanol. Ekstrak yang diperoleh dilakukan pengujian skrining aktivitas antibakteri pada kosentrasi $1 \mathrm{mg} / \mathrm{mL}$ pada medium Nutrien Agar (NA) menggunakan bakteri uji Basillus subtilis, Escherichia coli, Staphylococcus aureus, Pseudomonas aeruginosa, Streptococcus mutans, Staphylococcus epidermidis dan Shigella dysentriae menunjukkan bahwa ekstrak etanol aktif terhadap bakteri uji Escherichia coli, Pseudomonas aeruginosa, dan Streptococcus mutans.

Hasil skrining aktivitas antibakteri yang diperoleh dilanjutkan pada pengujian Kosentrasi Hambat Minimum (KHM) dengan tujuan untuk mengetahui kosentrasi berapa yang terendah ekstrak menghambat pertumbuhan bakteri uji yang digunakan. Hasil pengujian aktivitas berdasarkan KHM pada medium Nutrien Broth (NB) menggunakan ekstrak etanol batang tumbuhan Phytocrene macrophylla Blume. pada kosentrasi $0.2 \%, 0.4 \%, 0.6 \%, 0.8 \%$, $1 \%, 5 \%, 10 \%$ dan $15 \%$ diperoleh nilai KHM ekstrak etanol pada kosentrasi
0.4\% terhadap bakteri Escherichia coli, Pseudomonas aeruginosa, dan Streptococcus mutans. Hasil pengujian KHM ekstrak etanol yang diperoleh dilanjutkan dengan pengujian Pengujian Kosentrasi Bunuh Minimum (KBM) dengan tujuan untuk memperoleh kosentrasi ekstrak yang dapat membunuh terhadap pertumbuhan bakteri uji.

Hasil pengujian Kosentrasi Bunuh Minimum (KBM) menggunakan kosentrasi $0.2 \%, 0.4 \%, 0.6 \%, 0.8 \%$, $1 \%, 5 \%, 10 \%$ dan $15 \%$ dalam medium Nutrien Agar (NA) menunjukkan bahwa ekstrak etanol batang tumbuhan Phytocrene macrophylla Blume. diperoleh nilai KBM ekstrak etanol pada kosentrasi $0.8 \%$ terhadap bakteri uji, Pseudomonas aeruginosa, dan Streptococcus mutans sedangkan pada kosentrasi $1 \%$ aktif terhadap bakteri Escherichia coli.

Pengujian aktivitas antibakteri ekstrak etanol batang tumbuhan Phytocrene macrophylla Blume. dengan metode difusi agar bertujuna untuk menentikan kosentrasi berapa ekstrak dapat menghambat pertumbuhan bakteri uji yang digunakan. Pengujian aktivitas ini menggunakan beberapa variasi kosentrasi ekstrak yaitu $0.8 \%, 1 \%$ dan $5 \%$ menunjukkan bahwa kosentrasi 
Aktivitas antibakteri ekstrak etanol batang Phytocrene macrophylla Blume.

ekstrak tersebut dapat menghambat pertumbuhan bakteri uji Escherichia coli, Pseudomonas aeruginosa, dan Streptococcus mutans. Dimana pada kosentrasi $0.8 \%, 1 \%$ dan $5 \%$ diperoleh diameter zona hambata terbesar pada kosentrasi $5 \%$ terhadap bakteri Pseudomonas aeruginosa dan Streptococcus mutans dengan diameter zona hambat sebesar 16 $\mathrm{mm}$, terhadap bakteri Escherichia coli dengan diameter zona hambat sebesar $14 \mathrm{~mm}$. Berdasarkan hasil pengukuran diameter zona hambat tersebut menunjukkan bahwa ekstrak etanol batang tumbuhan Phytocrene macrophylla Blume. termasuk dalam golongan diameter zona hambat sedang.

\section{KESIMPULAN}

Ekstrak etanol batang tumbuhan Phytocrene macrophylla Blume. memiliki aktivitas terhadap bakteri Escherichia coli, Pseudomonas aeruginosa, dan Streptococcus mutans. Hasil pengujian aktivitas antibakteri diperoleh nilai Kosentrasi Hambat Minimum (KHM) pada kosentrasi $0.4 \%$ aktif terhadap bakteri uji Escherichia coli, Pseudomonas aeruginosa, dan Streptococcus mutans. dan nilai Kosentrasi Bunuh Minimum (KBM) 0.8\% aktif terhadap bakteri Pseudomonas aeruginosa, dan
Streptococcus mutans sedangkan nilai KBM pada kosentrasi $1 \%$ aktif terhadap bakteri Escherichia coli. Aktivitas antibakteri ekstrak etanol batang tumbuhan Phytocrene macrophylla Blume. diperoleh diameter zona hambat terbesar pada kosentrasi $5 \%$ yaitu sebesar $16 \mathrm{~mm}$ terhadap bakteri Pseudomonas aeruginosa, dan Streptococcus mutans sedangkan pada bakteri Escherichia coli sebesar $14 \mathrm{~mm}$.

\section{DAFTAR PUSTAKA}

1. Darmadi. Infeksi Nosokomial Problematika Dan Pengendaliannya. Jakarta : Salemba Medika Indonesia; 2008.

2. Saputri N. Aktivitas Antibakteri Ekstrak Etanol Batang Phytocrene macrophylla Blume. Secara KLTBioautografi (Skripsi). Makassar : Fakultas Farmasi, Universitas Muslim Indonesia; 2015.

3. Djide NM, Sartini. Mikrobiologi Farmasi Dasar. Makassar : Laboratorium Mikrobiologi Farmasi dan Bioteknologi Farmasi, Fakultas MIPA, Universitas Hasanuddin; 2005.

4. Djide NM, Sartini. Analisis Mikrobiologi Farmasi. Makassar : Laboratorium Mikrobiologi Farmasi dan Bioteknologi Farmasi, Fakultas MIPA, Universitas Hasanudin; 2008.

5. Holt JG. Bergey's Manual of Determinative Bacteriology $10^{\text {th }}$ Edition. United State of America : The Williams \& Wilkins Company, Baltimore, Maryland; 2000 